\title{
SORBS2 Gene
}

National Cancer Institute

\section{Source}

National Cancer Institute. SORBS2 Gene. NCI Thesaurus. Code C126602.

This gene plays a role in the formation of signaling protein complexes. 